\title{
Bedrock Geology, Physical and Physico-Chemical Properties of Teak Plantation Soil in Southwest Nigeria
}

\author{
F. O. Ogundele ${ }^{1} \&$ S. G. Odewumi ${ }^{1}$ \\ ${ }^{1}$ Department of Geography and Planning, Faculty of Social Sciences, Lagos State University, Nigeria \\ Correspondence: F. O. Ogundele, Department of Geography and Planning, Faculty of Social Sciences, Lagos \\ State University, Nigeria. E-mail: kunleoguns@yahoo.co.uk
}

Received: April 28, 2012 Accepted: May 15, 2012 Online Published: July 13, 2012

doi:10.5539/jgg.v4n3p56 URL: http://dx.doi.org/10.5539/jgg.v4n3p56

\begin{abstract}
The high rate of demand for this exotic timber product all over the world might have led to the over exploitation which has equally led to the current decline in the soil nutrient. This study therefore examined the differences in the soil physico-chemical properties of Teak plantations under basement and sedimentary rocks in south western Nigeria. 72 soil samples were collected; 36 from each of the two plantations underlying by Sedimentary and Basement complex of Ilaro and Olokemeji respectively. 12 Soil samples each from 3 quadrants each of $30 \mathrm{~m}^{2}$ were selected from each age i.e. 1970, 1972 and 1975 within a site respectively across the two sites. Bulked soil samples were collected each from horizon A and B of topsoil and subsoil with depth of $0-15 \mathrm{~cm}$ and $15-30 \mathrm{~cm}$ respectively. Also, 18 soil samples 9 from each site were collected from 3 profiles section from their A, B and C-Horizons. All these samples were analysed for their physico-chemical parameters such as Electrical Conductivity (EC), pH, Total Dissoved Solid (TDS) and Temperature. Results of the physico-chemical parameters revealed higher values of EC and TDS in the top soil of the plantation underlain by basement complex rock while that underlain by sedimentary rock showed higher values in the subsoil. This is attributed to higher porosity in the sedimentary rock which encourage leaching of nutrients and minerals to the subsoil while fine grains soil of the residual soil of the basement rocks accommodate nutriens and mineral entrapments on the top soil. On the other hand $\mathrm{pH}$ in soil of both bedrocks geology revealed low values. The low values in Olokemeji plantations could be attributed to the weathering of granitic rocks which are acidic while that of Ilaro could be attributed to acid rain from nearby industial and automobile exhaust from Agbara and ewekoro.
\end{abstract}

Keywords: bedrock geology, parent rock materials, physical properties, physico-chemical properties, soil nutrients

\section{Introduction}

Plantation forestry forms an important alternative means of wood production in the tropics and has been practiced for long time throughout the tropical countries since the colonial period by the expansion of forest plantations. Teak tree species is in high demand by the timber trade it is difficult to grow in plantations, (Raymond, 1996). The high rate of demand for this exotic timber product all over the world might have led to the over exploitation which has equally led to the current decline in the world natural forest cover. However, the productivity of Teak in most of the countries where they are grown in commercial quantities is generally below their potential.

According to Ombina (2008), the limiting factors explaining the current lower supplies of teak from tropical countries are multiple among which are the species suitability related to the edaphic factors and the land availability for plantations. While the edaphic factors are dictated by nature and have often been improved through different land management practices, the availability of' land imposed by human settling is often the most limiting factor faced by forestry agencies. Therefore, there is need to carry out research on the ecological factors responsible for the change in the productivity level of teak, especially in the area of the soil in order to sustain the world demand for the exotic timber consumption in the tropical environment.

However, the knowledge of nutrient quantity in the nutrient stock of the soil, above- and below ground biomass is of fundamental importance to the understanding of a forest ecosystem. A deeper insight into nutrient dynamics is also a precondition for guaranteeing ecological sustainability in these forest plantations (George et al., 1990). 
In tropical forests, most of the nutrients can be found in the active tree tissues, such as leaves (Whittaker et al., 1979).

The outcome of this study will form the basis for the formulation of better silviculture management strategy for the cultivation of Teak and to establish the best geological formations suitable for the growth of Teak and which will recycle and restore soil nutrients on time. Also, knowledge of the productivity (especially the stem-wood biomass) of the species under different geological formations will also be essential to justify differences recorded in timber production under different geological formations which is currently lacking for Tectona-grandis in the study area. In addition, a monitoring system for detecting changes in critical site parameters (especially biophysical and chemical characteristics) under different geological formations is expected to be designed for silviculture monitoring purposes which is one of the major contribution this research intend to add to the study of bio-geomorphology.

The aim of this study examined the differences in the soil physico-chemical properties of Teak plantations under basement and sedimentary rocks in south western Nigeria. In order to actualize the above aim, the research hypothesis is that there are no significant differences in the physic-chemical properties of soil of Teak plantations under the basement and sedimentary rocks in the study sites.

\section{Study Location and Methodology}

Two forest reserves located in south-western Nigeria are purposively selected for this study. The reserves fall within the hot humid tropics which support the tropical rainforest ecosystem (Richards, 1952). The two selected reserves are predominantly single-specie plantations of Tectona Grandis located in Olokemeji and Ilaro with large areas of land committed to forest reserves in Ogun state. The two reserves are known to have been sources of enormous economic benefits to Ogun state over the years (e.g. Adeyoju, 1971; Okali \& Onyeachusim, 1991) because of their rich wood resources.

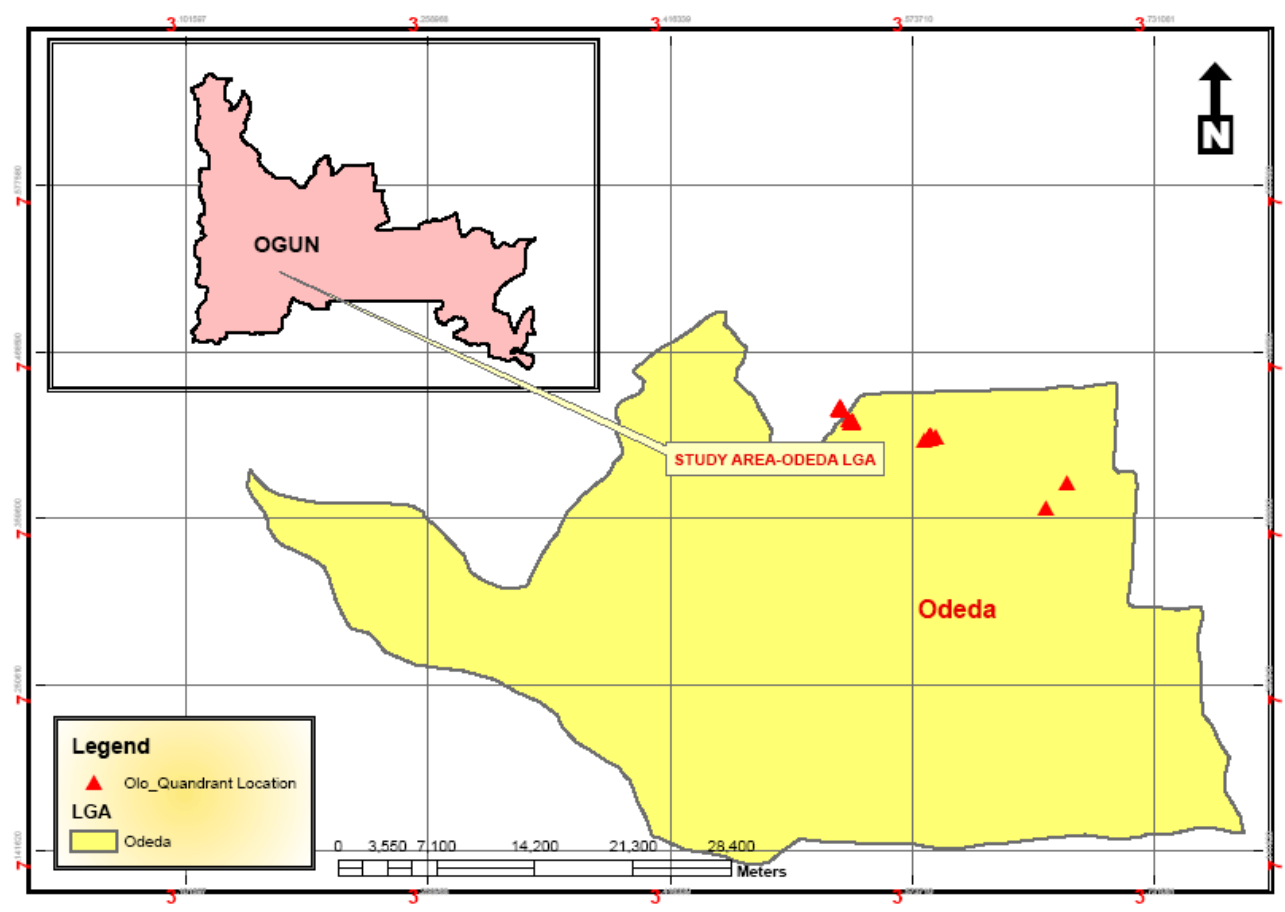

Figure 1. Location map of Olokemeji teak plantation 


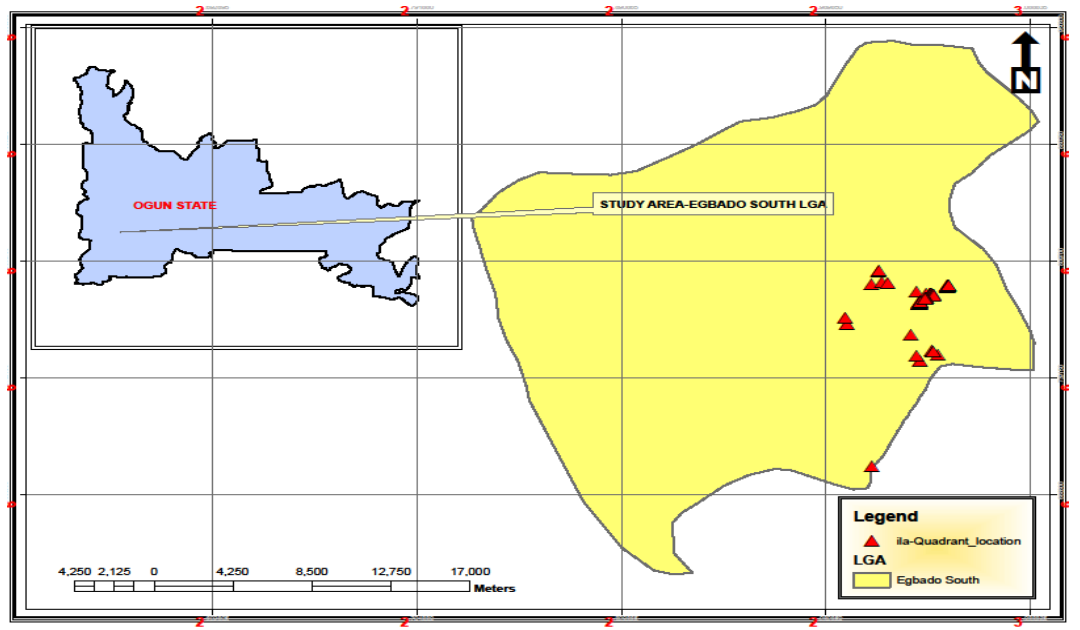

Figure 2. Location map of Ilaro Teak Reserve

\subsection{Location and Extent of Olokemeji and Ilaro Plantations}

The Olokemeji teak plantation is located in the heart of Olokemeji forest reserve located between latitudes $7^{\circ} 05^{\prime}$ and $7^{\circ} 40^{\prime} \mathrm{N}$ and longitudes $3^{\circ} 15^{\prime}$ and $3^{\circ} 46^{\prime} \mathrm{E}$ and occupies a total land area of $58.88 \mathrm{~km}^{2}$ (approximately 5,000 hectares) (Aminu-Kano \& Marguba, 1901). The reserve, which was established in 1899 is the second forest reserve in Nigeria. The site lies approximately $32 \mathrm{~km}$ west of Ibadan, and $35 \mathrm{~km}$ north-east of Abeokuta. It falls within the middle course of Ogun River, which drains the western half of the Basement Complex area of South Western Nigeria. On the other hand, geographically, Ilaro is bounded on the north by the Oyo Province, on the South by Lagos, on the east by the Egba Division and on the west by Dahomey (Republic of Benin). The boundary on the South is defined in the "Colony of Nigeria boundaries order in council 1913" (see page 311 of Vol IV laws of Nigeria). Ilaro forest reserve is defined roughly by latitude $0638^{\prime} 51.36 \mathrm{~N}$ and $0657^{\prime} 24.40 \mathrm{~N}$ and Longitude $024906.12^{\prime} \mathrm{E}$ and 0310 43.60' E. This reserve covers an area of about $34.2 \mathrm{~km}$ by $39.9 \mathrm{~km}$.

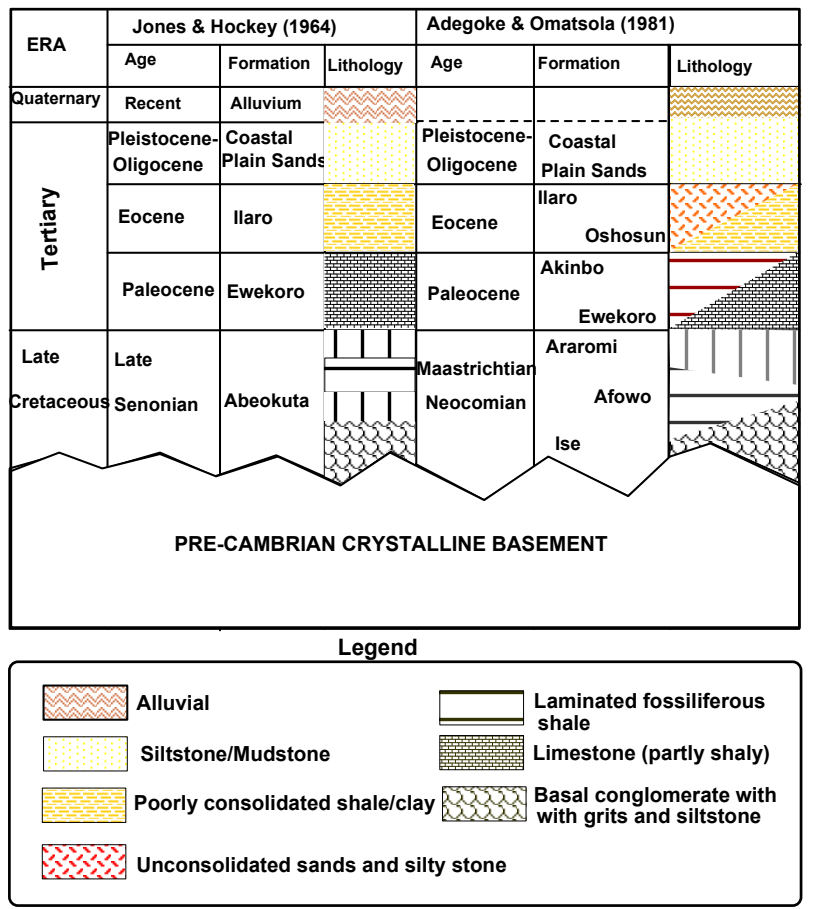

Figure 3. Stratgraphic description of Eastern Dahomey Basin

Source: Adapted from Ako et al., 1980 in Onakomaiya et al., 1992 
Table 1. Stratigraphic analysis of the study area

\begin{tabular}{cll}
\hline \multicolumn{1}{c}{ Age } & Units & Lithology \\
\hline & Ilaro & Sandstone \\
Maestrict-Paleocene Eocene Chain & Oshosun & Shale \\
& Ewekoro & Limestone \\
& Abeokuta & Sandstone \\
\hline
\end{tabular}

Source: Adapeted from Ako et al., 1980 in Onakomaiya et al., 1992

\subsection{Plantation Sampling Techniques}

Sampling design for this study was based on two premises, first, the need to spread sample sites objectively over the study area and second, the needs to ensure that plant and site characteristics are adequately depicted.

Therefore, in order to obtain detailed soil and plant representation, one Teak reserves each established on Basement Complex and Sedimentary formation parent rocks were purposefully selected and divided into plantation quadrants based on the information extracted from the forest resources study of Nigeria published by FORMECU in 1999. The two teak reserves are Olokemeji and Ilaro in Ogun State, Southwest Nigeria. The two selected teak reserves are distinctively established under basement complex (Olokemeji) and sedimentary (Ilaro) formations respectively (Kogbe, 1976; Hushley, 1976). The choice of Teak as the study species is because of its high quality as hardwood which led to its high demand and also because almost $90 \%$ of the timber species in the two plantation are Teak species.

According to FORMECU (1999), Olokemeji reserve has 15 Teak plantations of 50 hectares of 750 hectares while Ilaro forest has 11 Teak plantations of 550 hectares of fifty (50) hectares sizes. The twenty-six (26) teak plantations were established between 1970, 1972 and 1975 across the two sites which make them 41, 39 and 36 years old respectively. Therefore, due to the uniformity in the area sizes and the ages of the plantations, random and systematic sampling techniques were adopted to select the quadrant plots where various soil and plant samples were collected.

\subsection{Soil Sampling Techniques}

Out of the 26 plantations of 750 and 550 hectares for Olokemeji and Ilaro respectively, six plantations (three each under the basement complex (Olokemeji reserve) and sedimentary (Ilaro reserve) were sub-divided into quadrant plots. This is possible because of the uniformity in plantations sizes and ages based on the records of the Nigeria Forest Inventory carried out BEAK Consults/ FORMECU published in 1999 (FORMECU, 1999). Therefore, in each of the six sampled plantations, 1000 metre long transect was laid from the edge of each plantations as identified by the forest official. Along each of the major transect, 10 sample plots with the size of $900 \mathrm{~m}^{2}(30 \mathrm{~m} \times 30 \mathrm{~m})$ were laid consistently at a right angle to the main transect with the aid of GPS and pegs, making a total of sixty (60) plots for the two sites from where eighteen (18) plots (quadrants) for each site and thirty six (36) for the two sites were randomly selected for enumeration. Data were collected in the 36 sample plots from the six transects representing $0.2769 \%$.

In each plot (quadrant), five (5) soil samples each were collected from the A-Horizon of 0-15 cm and B-Horizon of 15-30 cm representing the top and sub-soils respectively, making a total of ten (10) samples per quadrant plot. The restriction of soil samples to $0-15 \mathrm{~cm}$ and $15-30 \mathrm{~cm}$ depth was adopted because the layer provides the bulk of plant nutrients (Russell, 1978). With this, a total of sixty (60) soil samples were collected for the two Horizons per plantation while in all, a total of three hundred and sixty (360) samples were collected from the six plantations for the whole study covering the two parent material.

The soil samples collected were later bulked to reduce the sample size. According to Cameron et al. (1971), four aliquots from each grid cell situated from the sides of the cell plus one at the grid centre are sufficient for grid cell of $30 \mathrm{~m} \times 30 \mathrm{~m}$ size.Following Cameroun et al. (1971) sampling procedure, the soil samples collected diagonally from five points in each plot at each horizon were later bulked to make one sample per horizon per plot and two samples for the two horizons per plot with a total of six soil samples per horizon per quadrants plot and twelve (12) soil samples for the two horizons per plantation. Therefore, the total soil samples for the three plantations per geological site after bulking were reduced to eighteen (18) per horizon and thirty-six (36) for the two horizons to make a total of seventy-two (72) samples for the entire study for the two horizons. 


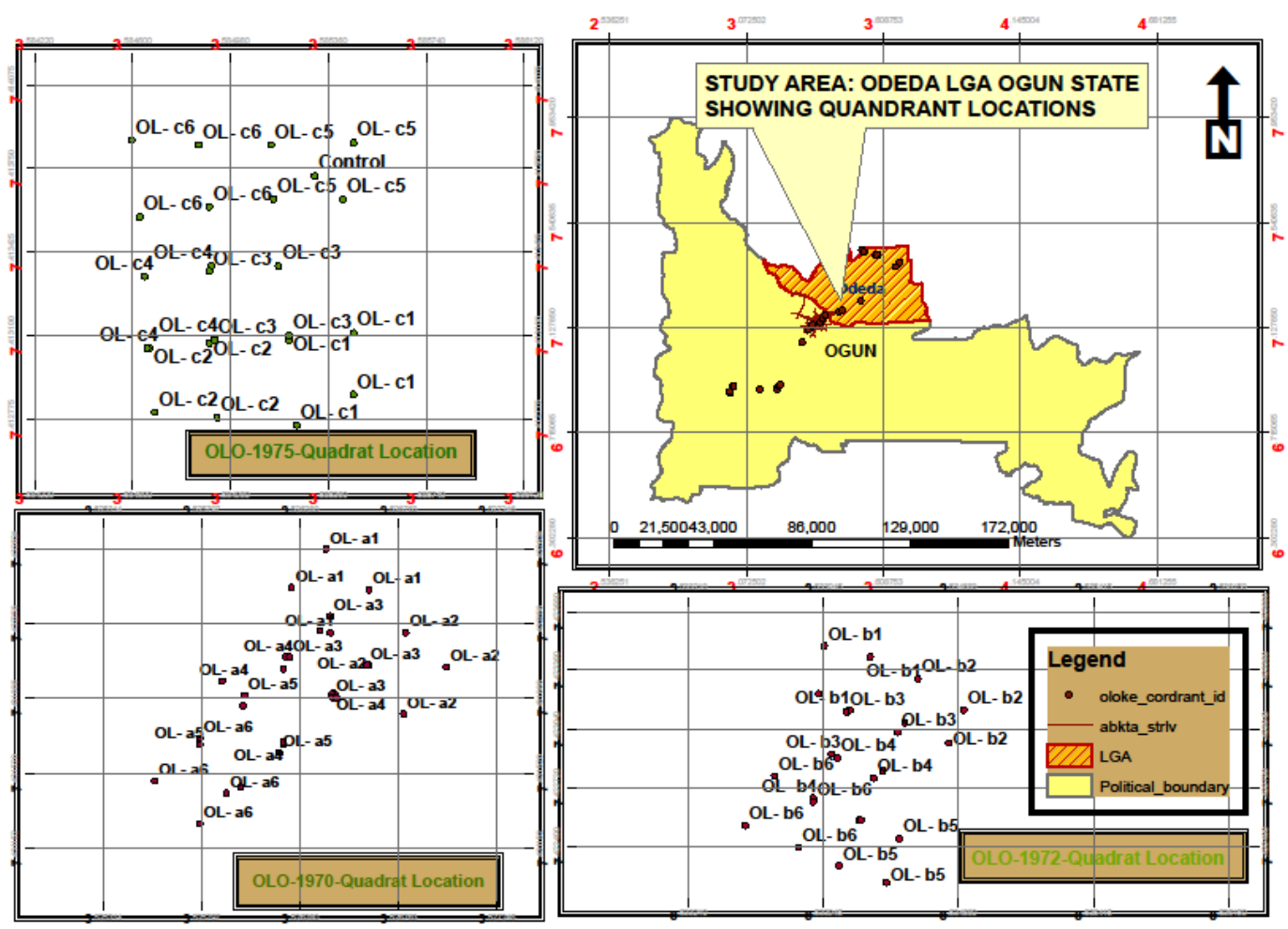

Figure 4. Sampling points for Ilaro Plantattion

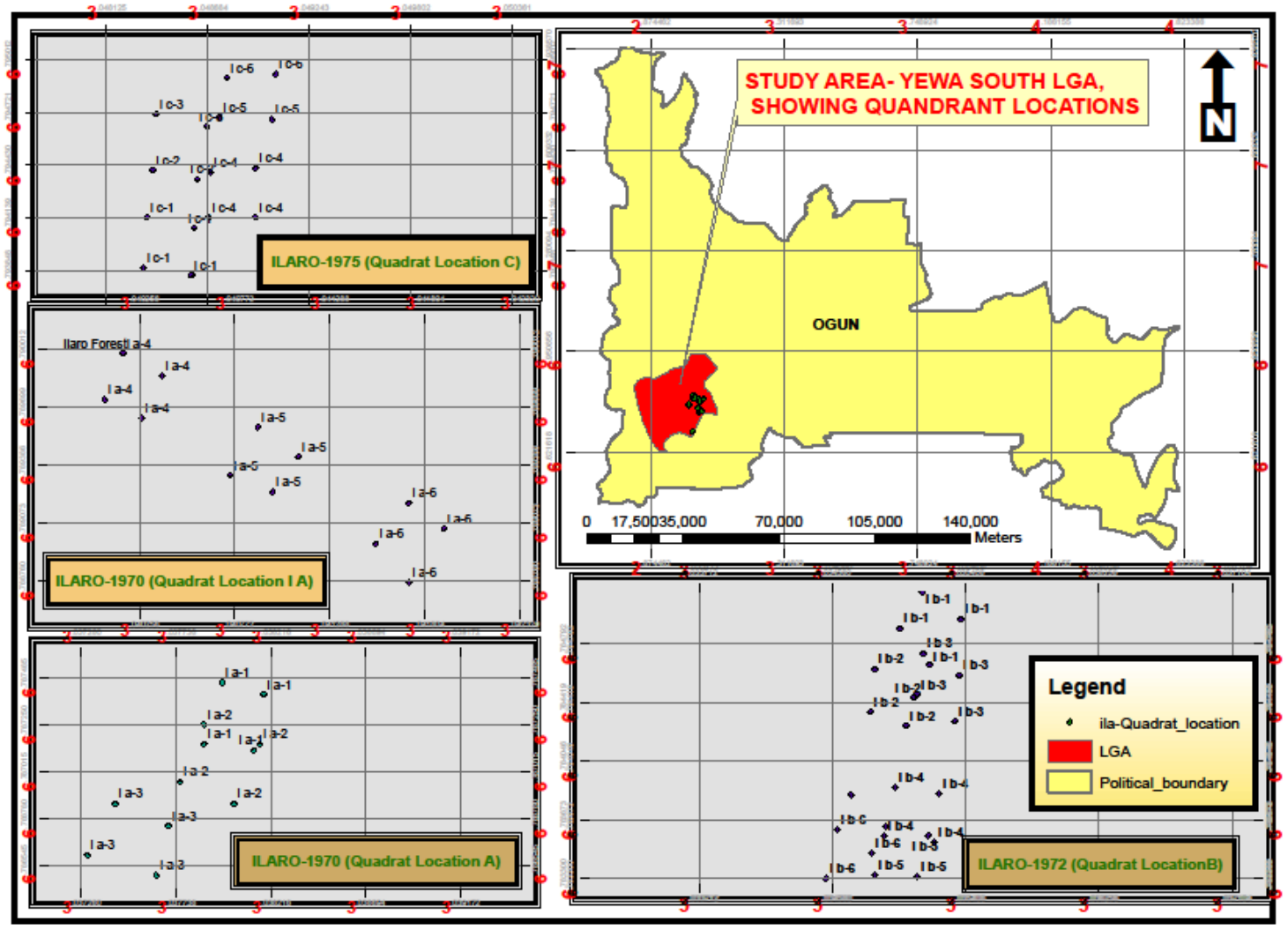

Figure 5. Sampling points for Ilaro Plantattion 
Table 2. Summary of laboratory analytical methods employed

\begin{tabular}{lll}
\hline S/N & Parameter & Method \\
\hline 1. & PH & Electrometric \\
2. & Organic carbon & Walkey and Black \\
3. & Total Nitrogen & Kjedhal/Colorimetry \\
4. & Salinity as chloride & Orion 105plus meter \\
5. & Available phosphorus & Bray P-1 \\
6. & Electrical conductivity & Conductivity meter \\
7. & Metals & Atomic absorption spectrophotometry [using Perkin Elmer 2380 AAS] \\
8. & Anions & Spectrophotometry using Palintest 5000 Photometer \\
\hline
\end{tabular}

\subsection{Statistical Analysis}

Data Analysis was carried out using the following tools. The data were subjected to different analysis.

$>$ Descriptive statistics: This include statistic such as the mean (Arithmetic mean) and the Standard Deviation as well as standard error of mean of each of the indices. The analysis of means was also considered to look at each of the statistics by different interaction (Site by year or Site by plot).

$>$ Generalized Linear Model: This was executed using the GLM of SAS version 9. Under this GLM, different sources of variation including both main and interaction effect were investigated.

Also, analysis of means for the main factors-Geographic-sites, plantation age and plots as well as interaction effects of geographic location and plantation age and location and plots. Also, mean separation of the different sources of variation was done using Duncan Multiple range test of the SAS version 9 and Factor analysis was carried out using principal component analysis of the MINITAB (version 17). Specifically, one-way analysis of variance (ANOVA) was conducted for detecting statistically significant differences in soil physicochemical properties, biomass production and distribution, tree nutrient concentrations across geological formations at 0.05 and 0.001 significance levels.

\section{Results of the Soil Physico-chemical Parameters}

The results of the analysis necessary to achieving the set objective for this work include the Physico-chemical parameters of the soils in two sites, under different ages of 1970, 1972 and 1975 respectively. Physico-chemical parameters, such as Soil $\mathrm{pH}$, Total Dissolved Solid (TDS) in $\mathrm{mg} / \mathrm{l}$, Electrical Conductivity (EC) in $\mu \mathrm{s} / \mathrm{cm}$ and Temperature $(\mathrm{T})$ in ${ }^{\circ} \mathrm{C}$. All these were measured in-situ in order to avoid any possible alterations in their characteristics with change in the environmental conditions. Tables below show the statistical summary of those parameters as earlier mentioned.

The result of $\mathrm{pH}$ for A Horizon of the soil in 1970 revealed the range values of $(5.6 \pm 0.12,4.80 \pm 1.40),(4.4 \pm 1.0$, $8.33 \pm 9.30)$ with average value of $(4.8,4.4),(4.0,4.1)$ and Standard deviation of $(0.46,0.53),(0.38,0.43)$ for A and B Horizon in Olokemeji and Ilaro plantations respectively. The 1972 plantation revealed range values of $(5.2 \pm 0.6,5.0 \pm 1.8),(5.30 \pm 0.50,6.10 \pm 1.90)$ with average values of $(4.9,4.5),(5.1,4.8)$ and Standard deviation of $(0.21,0.69),(0.16,0.70)$ for $\mathrm{A}$ and $\mathrm{B}$ horizon in Olokemeji and Ilaro Plantation respectively while 1975 plantation revealed $\mathrm{pH}$ range value of $(4.9 \pm 0.08,5.00 \pm 0.40),(6.8 \pm 1.6,1.10)$ with average value of $(4.7,4.9)$, $(5.6,5.9)$ and Standard deviation of $(0.30,0.13),(0.62,0.46)$ for the A and B horizon in Olokemeji and Ilaro plantations respectively

The EC in 1972 plantation revealed the range value of $(170 \pm 140,170 \pm 129),(124 \pm 87,21 \pm 5.0)$ with average value of $(94,81),(61,4)$ and Standard deviation of $(44.9,48.3),(32.9,30.2)$ for the A and B horizon and Olokemeji and Ilaro respectively. On the other hand, the 1972 plantation revealed the range values of $(141 \pm 111$, $77 \pm 57),(100 \pm 72,70 \pm 60)$ with average value of $(58.8,47.3),(59.7,39.0)$ and Standard deviation of $(41.9,26.70)$, $(28.9,24.3)$ for the A and B and Olokemeji and Ilaro plantation respectively, while the 1975 plantation reveal the range values of $(272 \pm 206,163 \pm 124),(50 \pm 22,204 \pm 192)$ with average values of $(109,77),(40,56)$ and Standard deviation value of $(80.1,43.6),(8.1,73.1)$ for the A and B horizon in Olokemeji and Ilaro respectively.

The Total dissolved solid in 1970 plantation revealed a range value of $(128 \pm 105,129 \pm 98),(93 \pm 65,65 \pm 16)$ with average value of $(70.7,60.9),(46,41)$ and Standard deviation value of $(33.7,36.8),(24.7,30.9)$ for And B in Olokemeji and Ilaro plantation respectively. On the other hand, in 1972, TDS revealed a range value of (106 \pm 83 , 
$58 \pm 43),(75 \pm 54,53 \pm 45)$ with average values of $(59,47),(45,30)$ and Standard deviation of $(31,20),(22,18)$ for $\mathrm{A}$ and $\mathrm{B}$ horizon and Olokemeji and Ilaro Plantation respectively while for 1975 plantation, it revealed the range values of $(204 \pm 156,122 \pm 88),(38 \pm 17,153 \pm 144)$ with average values of $(82,58),(30,42)$ and Standard deviation value of $(60,32),(6,55)$ for A and B horizon in Olokemeji and Ilaro respectively.

The soil Temperature in 1970 plantation revealed the range value of $(30 \pm 1,30.40 \pm 1.70),(30.7 \pm 0.03,18.20 \pm 2.59)$ with average values of $(29,30),(31,0.1)$ and Standard deviation of $(0.34,0.65),(0.14,0.26)$ for A and B in Olokemeji and Ilaro plantations respectively. For 1972, the range values of $(30 \pm 0.07,29.80 \pm 0.60),(30.8 \pm 1.0$, $30.40 \pm 0.30)$ with average value of $(30,29),(30,30)$ and Standard deviation of $(0.27,0.21),(0.37,0.14)$ were revealed for A and B horizon in Olokemeji and Ilaro Plantation respectively. While for 1975, the range values of $(30.1 \pm 0.09,30 \pm 0.70),(30.4 \pm 0.70,30.30 \mathrm{v} 0.40)$ with average values of $(30,30),(30,30)$ and Standard deviation of $(0.35,0.24),(0.26,0.15)$ for A and B horizon in Olokemej and Ilaro plantations respectively.

Table 3.1a. Statistical Summary of Olokemeji Physicochemical Parameters Planted 1970

\begin{tabular}{lllllllll}
\hline 1970 & \multicolumn{3}{l}{ A HORIZON } & \multicolumn{5}{c}{ B HORIZON } \\
\hline PARAMETER & AVER & MIN & MAX & STDEV & AVER & MIN & MAX & STDEV \\
\hline PH & 4.76667 & 4.4 & 5.6 & 0.46 & 4.40 & 3.40 & 4.80 & 0.53 \\
E.C (us/cm) & 94.00 & 30 & 170 & 44.92 & 80.83 & 41.00 & 170.00 & 48.33 \\
TDS (mg/l) & 70.6833 & 23 & 128 & 33.71 & 60.92 & 31.00 & 129.00 & 36.76 \\
TEMP C & 29.48 & 29 & 30 & 0.34 & 29.50 & 28.70 & 30.40 & 0.65 \\
\hline
\end{tabular}

Table 3.1b. Statistical Summary of Olokemeji Physicochemical Parameters Planted 1972

\begin{tabular}{lllllllll}
\hline 1972 & A HORIZON & \multicolumn{5}{c}{ B HORIZON } \\
\hline PARAMETER & AVER & MIN & MAX & STDEV & AVER & MIN & MAX & STDEV \\
\hline PH & 4.85 & 4.6 & 5.2 & 0.21 & 4.45 & 3.20 & 5.00 & 0.69 \\
E.C (us/cm) & 58.83 & 30 & 141 & 41.92 & 47.33 & 20.00 & 77.00 & 26.70 \\
TDS (mg/l) & 44.3333 & 23 & 106 & 31.40 & 35.58 & 15.00 & 58.00 & 20.11 \\
TEMP $\odot$ C & 29.67 & 29.3 & 30 & 0.27 & 29.38 & 29.20 & 29.80 & 0.21 \\
\hline
\end{tabular}

Table 3.1c. Statistical Summary of Olokemeji Physicochemical Parameters Planted 1975

\begin{tabular}{lllllllll}
\hline 1975 & \multicolumn{3}{l}{ A HORIZON } & \multicolumn{5}{c}{ B HORIZON } \\
\hline PARAMETER & AVER & MIN & MAX & STDEV & AVER & MIN & MAX & STDEV \\
\hline PH & 4.66667 & 4.1 & 4.9 & 0.30 & 4.82 & 4.60 & 5.00 & 0.13 \\
E.C (us/cm) & 109.17 & 64 & 272 & 80.05 & 76.83 & 39.00 & 163.00 & 43.63 \\
TDS (mg/l) & 82.1667 & 48 & 204 & 59.91 & 57.83 & 30.00 & 122.00 & 32.47 \\
TEMP $\odot$ & 29.58 & 29.2 & 30.1 & 0.35 & 29.55 & 29.30 & 30.00 & 0.24 \\
\hline
\end{tabular}


Table 3.2a. Statistical Summary of Ilaro Physicochemical Parameters Planted 1970

\begin{tabular}{|c|c|c|c|c|c|c|c|c|}
\hline 1970 & A HOR & $\mathrm{ZON}$ & & & B HORI & $\mathrm{ZON}$ & & \\
\hline PARAMETER & AVER & MIN & MAX & STDEV & AVER & MIN & MAX & STDEV \\
\hline PH & 4 & 3.4 & 4.4 & 0.38 & 4.07 & 38.33 & 28.83 & 30.43 \\
\hline E.C (us/cm) & 61.17 & 37 & 124 & 32.88 & 4.00 & 21.00 & 16.00 & 30.20 \\
\hline TDS (mg/l) & 46 & 28 & 93 & 24.65 & 4.10 & 65.00 & 49.00 & 30.90 \\
\hline TEMP @ & 30.53 & 30.4 & 30.7 & 0.14 & 0.05 & 18.20 & 13.61 & 0.26 \\
\hline
\end{tabular}

Table 3.2b. Statistical Summary of Ilaro Physicochemical Parameters Planted 1972

\begin{tabular}{lllllllll}
\hline 1972 & A HORIZON & \multicolumn{5}{c}{ B HORIZON } \\
\hline PARAMETER & AVER & MIN & MAX & STDEV & AVER & MIN & MAX & STDEV \\
\hline PH & 5.06667 & 4.8 & 5.3 & 0.16 & 4.78 & 4.20 & 6.10 & 0.70 \\
E.C (us/cm) & 59.67 & 28 & 100 & 28.86 & 39.00 & 10.00 & 70.00 & 24.33 \\
TDS (mg/l) & 44.8333 & 21 & 75 & 21.51 & 29.50 & 8.00 & 53.00 & 18.12 \\
TEMP ( $)$ & 30.10 & 29.8 & 30.8 & 0.37 & 30.25 & 30.10 & 30.40 & 0.14 \\
\hline
\end{tabular}

Table 3.2c. Statistical Summary of Ilaro Physicochemical Parameters Planted 1975

\begin{tabular}{lllllllll}
\hline 1975 & \multicolumn{3}{l}{ A HORIZON } & \multicolumn{5}{c}{ B HORIZON } \\
\hline PARAMETER & AVER & MIN & MAX & STDEV & AVER & MIN & MAX & STDEV \\
\hline PH & 5.6 & 5.2 & 6.8 & 0.62 & 5.87 & 5.30 & 6.40 & 0.46 \\
E.C (us/cm) & 39.50 & 28 & 50 & 8.07 & 55.67 & 12.00 & 204.00 & 73.08 \\
TDS (mg/l) & 29.6667 & 21 & 38 & 6.15 & 41.83 & 9.00 & 153.00 & 54.78 \\
TEMP ( & 29.95 & 29.7 & 30.4 & 0.26 & 30.08 & 29.90 & 30.30 & 0.15 \\
\hline
\end{tabular}

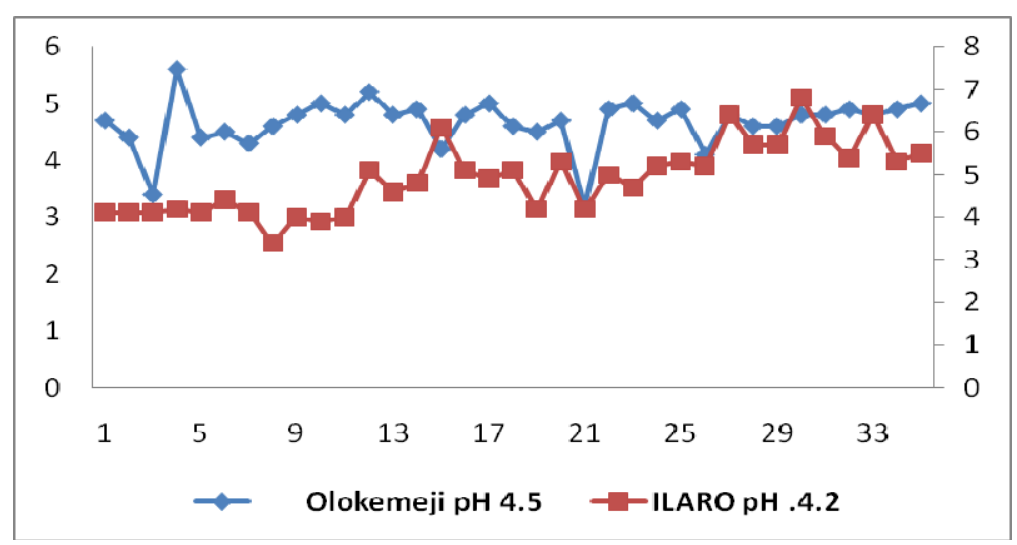

Figure 6.1. Linear plot showing the variation in $\mathrm{pH}$ across the two sites

Soil $\mathrm{pH}$ in both sites show range values of 3.2-5.6 and 3.4-6.8 with average values of 4.7 and 4.9 for Olokemeji and Ilaro respectively. The relatively low $\mathrm{pH}$ in Olokomeji plantation compared to Ilaro (see Figure 4.1) reveal the fact that they are of different bedrock geology (Parent rock materials) since Olokemeji is underlain by granitic rocks which are acidic in composition. In contrast to Ilaro which is underlain by sedimentary rocks specifically the fine to medium pebbly and unconsolidated sandstone of Ilaro formation Kogbe (1976). In addition the sandy nature of the area reduces the reactivity and neutralization action of the soil. The case of Olokemeji is contrary as it is acidic to slightly acidic which is due to the granitic rocks which are acidic igneous and granite gneiss of basement complex of south-western Nigeria. 
The results of the TDS and EC as shown in tables; 1a-c and 2a-c indicate higher values of both parameters in the A-horizon compare to the B-horizon. This is due to the higher activities in the topsoil than the subsoil due to higher oxygen, microorganism and nutrients for effective reaction. Though, this is not the case in few cases in Ilaro soil where the high values were observed in the B-horizon which is probably due to higher sand content which encourage leaching of nutrients down to B-horizon due to high porosity and permeability of the topsoil usually associated with sandy soil (see Figures 6.2a-b and 6.3a-b).

Linear plot for physicochemical parameters in A and B horizon in Olokemeji and Ilaro plantations respectively is also shown in Figures 4.2a-4.2b and this graphically shows how they vary in space at different soil depths. The analyses revealed that there is more concentration of EC, in A horizon of Olokemeji than A horizon of Ilaro plantation. On the contrary, the B horizon of Ilaro plantation is higher in EC value compared to the Olokemeji plantation (see Figures 4.2b and 4.3b). For total dissolve salts (TDS), the pattern did not follow the trend as observed in EC, rather, the A Horizon of Olokemeji fluctuate regularly with higher values while that of Ilaro recorded low values which tend towards zero, while the B horizon plantation follow the pattern of the A horizon in Olokemeji and the A horizon in Ilaro follows the pattern of the B horizon in Olokemeji (see Figures 7.2a-7.3c) this could be attributed to the higher porosity in the soil of Ilaro due to their sandy nature which encouraged leaching/trapping of mineral and nutrients in higher depth of the profile, Unlike Olokemeji soil with predominantly higher feldspas and biotite which their weathering and alterations result into finer grains soil such as clay.

Soil temperature of the A and B horizon across the two location maintain a regular pattern with little variation and this can be attributed to the fact that the shallow depth of the sampling profile (see Tables 3.1a-3.2c).

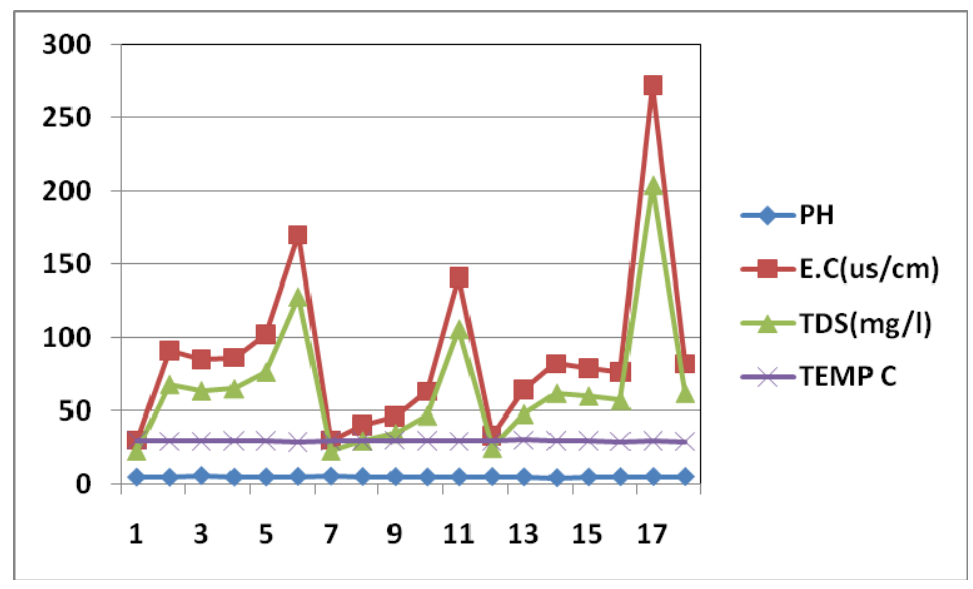

Figure 6.2a. Linear plot for physico-chemical Parameters in A-horizon Soil of Olokemeji

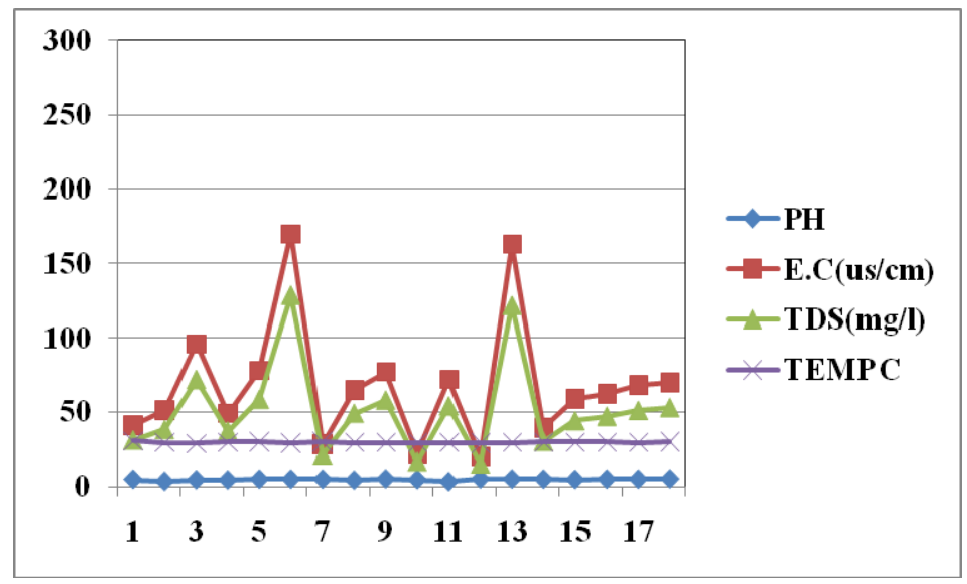

Figure 6.2b. Linear plot for physico-chemical Parameters in B-horizon Soil of Olokemeji 


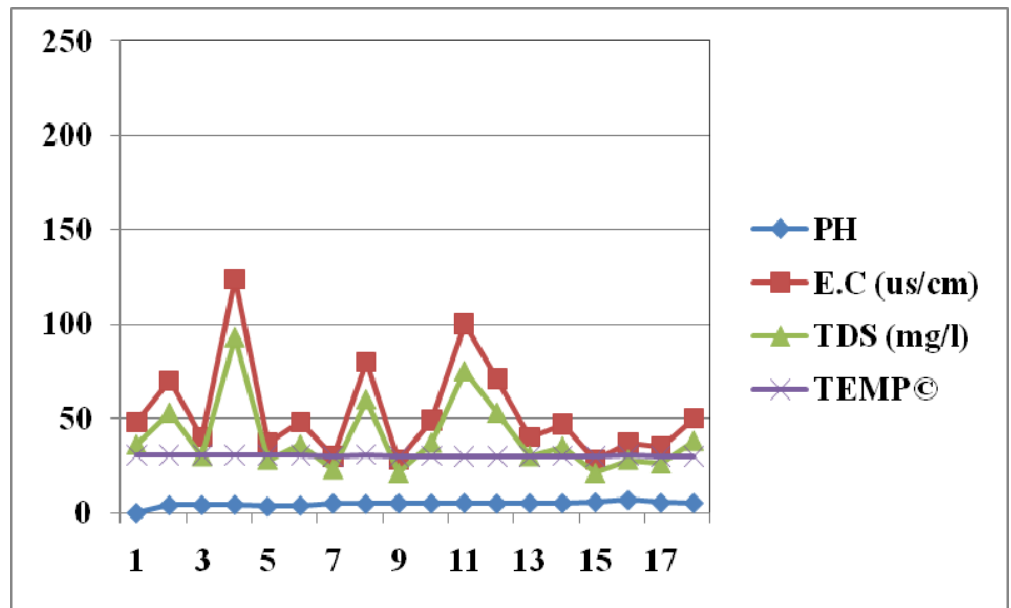

Figure 6.3a. Linear plot for physico-chemical Parameters in A-horizon Soil of Ilaro

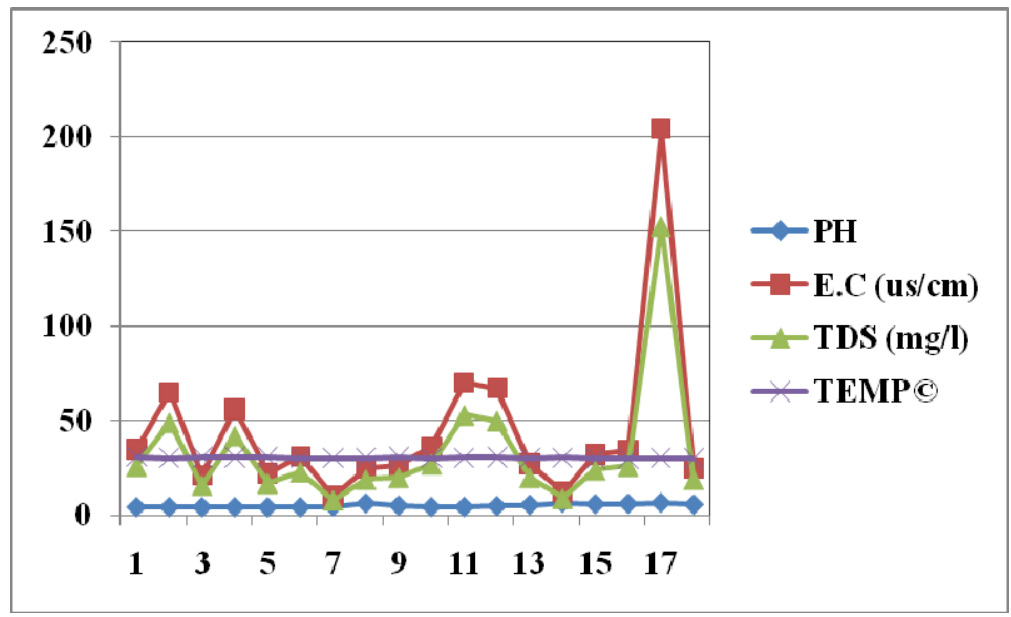

Figure 6.3b. Linear plot for physico-chemical Parameters in B-horizon Soil of Ilaro

\section{Results of the Soil Physical Properties}

Plants need anchorage, water and nutrients from the soil but are sensitive to excesses of growth impeding substances in the soil. The supply and uptake of nutrients from the soil is not a simple process but requires a suitable combination of various soil properties. Soil physical properties largely determine the texture, structure, physical condition and tilting of the soil. This in turn exert an important influence on potential rooting volume, penetrability of roots, WHC, degree of aeration, living conditions for soil life, and nutrient mobility and uptake ((Raymond \& Gardiner, 2001). These are as important as soil chemical properties. In this study, soil physical properties considered are; Hydraulic Conductivity, Water Holding Capacity (WHC), Bulk Density and Porosity. For hydraulic properties of the soils in the study area, the Soil class rating of hydraulic properties/characteristics of Food and Agricultural Organization (FAO, 1980), was adopted in this study as shown in Tables 4.3a, 4.3b and $4.3 \mathrm{c}$ with bar chat in the Figures $4.4 \mathrm{a}$ and $4.4 \mathrm{~b}$ below representing their class rating. The soils performance of the two location were determined and the results is further shown in Figures $4.4 \mathrm{a}$ and $4.4 \mathrm{~b}$ which shows that the bulk-density, EC and Porosity were rated as prime using the Food and Agriculture Organization Soil class rating with exception of hydraulic conductivity with low value others are high in Ilaro compare to what is obtainable in Olokemeji Plantation. 
Table 4.1. Statistical summary of the physical characteristics of the two sites

\begin{tabular}{lllllllll}
\hline SITE & \multicolumn{3}{l}{ OLOKEMEJI: N=18 } & \multicolumn{7}{l}{ ILARO: N=18 } \\
\hline PARAMETERS & AVER & MIN & MAX & STDEV & AVER & MIN & MAX & STDEV \\
\hline K (cm/min) & 0.781 & 0.049 & 1.331 & 0.348 & 0.695 & 0.25 & 1.387 & 0.290 \\
K (cm/hrs) & 46.833 & 2.94 & 79.86 & 20.907 & 42.359 & 15 & 83.22 & 17.175 \\
WHC & 50.606 & 33.9 & 74.1 & 13.804 & 51.906 & 28.6 & 72.1 & 11.988 \\
Bulk Density & 1.161 & 0.95 & 1.38 & 0.126 & 1.158 & 1.01 & 1.66 & 0.151 \\
Porosity & 56.144 & 47.9 & 64.2 & 4.766 & 55.619 & 37.4 & 61.9 & 5.454 \\
EC uS/cm & 86.563 & 30 & 272 & 62.550 & 52.722 & 28 & 124 & 26.517 \\
\hline
\end{tabular}

Hydraulic properties were measured on the soil from both sites, the results from Ilaro show hydraulic conductivity in $\mathrm{cm} / \mathrm{hr}$ range from 15-83.22, water holding capacity from 38.6-72.1, Bulk Density from 1.01-1.66 Porosity from 37.4-61.9 and electrical conductivity from 28-124 with average of 42.36, 51.91, 1.16, 55.62 and 52.72 respectively. Those of Olokemeji plantation reveal hydraulic conductivity in $\mathrm{cm} / \mathrm{hr}$ range from 2.94-79.86 water holding capacity from 33.9-74.1, Bulk Density from 0.95-1.38 Porosity from 47.9-64.2 and electrical conductivity from $30-272$ with average of $46.83,50.6,1.16,56.14$ and 86.56 respectively. The Soil class rating of hydraulic properties/characteristics of FAO 1980 was adopted in these studies as shown in Tables 4.3a, 4.3b and $4.3 \mathrm{c}$ with bar chat in the Figures $4.4 \mathrm{a}$ and $4.4 \mathrm{~b}$ below represent their class rating. Soil $\mathrm{pH}$ in both site show range values of 3.2-5.6 and 3.4-6.8 with average values of 4.7 and 4.9 for Olokemeji and Ilaro respectively. The relatively values of hydraulic conductivity in Ilaro compare to Olokemeji, which correlate well with the porosity and Bulk density could be attributed to large percentage of sand content with higher porosity, permeability and density. This is also justified by their relatively low water holding capacity with negative correlation. Olokomeji plantation soil is attributed to having higher clay fraction with higher values water holding capacity compared to Ilaro (see Figure 4.1) reveal the fact that they are of different bedrock geology (Parent rock materials) since Olokemeji is underlain by granitic rocks which are of feldsparthoid which in most cases weathered into clay mineral like kaolinite acidic in composition.

Table 4.1a. Hydraulic properties quality index rating adopted from FAO 1980

\begin{tabular}{|c|c|c|c|c|c|}
\hline Soil Quality Rating Class & Class 1 & Class 2 & Class 3 & Class 4 & Class 5 \\
\hline Soil Quality Parameters & Prime & Good & Medium & Marginal & Unsuitable \\
\hline Bulk Density/cm ${ }^{3}$ & $<1.25$ & $1.25-1.3$ & $1.3-1.5$ & $1.5-1.65$ & $>1.65$ \\
\hline Porosity Vol. \% & $>53$ & $51-53$ & $43-51$ & $38-43$ & $<38$ \\
\hline \multicolumn{6}{|l|}{ WHC mm of $\mathrm{H}_{2} \mathrm{O} \mathrm{m}$ Soil } \\
\hline Hydraulic Conductivity cm/hr & $50-80$ & $40-50$ & $40-10$ & $<10$ & $<10$ \\
\hline Electrical Conductivity us/cm & $<100$ & $100-400$ & $400-600$ & $600-800$ & $>800$ \\
\hline
\end{tabular}

Table 4.1b. Number of samples within each class in Olokemeji Plantation

\begin{tabular}{|c|c|c|c|c|c|}
\hline Soil Quality Rating Class & Class 1 & Class 2 & Class 3 & Class 4 & Class 5 \\
\hline Soil Quality Parameters & Prime & Good & Medium & Marginal & Unsuitable \\
\hline Bulk Density/cm3 & 11 & 3 & 2 & 1 & 1 \\
\hline Porosity Vol. \% & 13 & 3 & 2 & 0 & 0 \\
\hline \multicolumn{6}{|l|}{ WHC mm of $\mathrm{H}_{2} \mathrm{O} \mathrm{m}$ Soil } \\
\hline Hydraulic Conductivity & 8 & 5 & 4 & 1 & 0 \\
\hline Electrical Conductivity us $/ \mathrm{cm}$ & 13 & 3 & 1 & 1 & 0 \\
\hline
\end{tabular}


Table 4.1c. Number of samples within each class in Ilaro Plantation

\begin{tabular}{llllll}
\hline Soil Quality Rating Class & Class 1 & $\begin{array}{l}\text { Class 2 } \\
\text { Grime }\end{array}$ & $\begin{array}{l}\text { Class 3 } \\
\text { Geod }\end{array}$ & $\begin{array}{l}\text { Class 4 } \\
\text { Marginal }\end{array}$ & $\begin{array}{l}\text { Class 5 } \\
\text { Unsuitable }\end{array}$ \\
\hline $\begin{array}{llllll}\text { Bulk Density/cm3 } \\
\text { Porosity Vol. \% }\end{array}$ & 14 & 3 & 0 & 0 & 1 \\
WHC mm of H $\mathbf{O}$ m Soil & 14 & 3 & 0 & 0 & 1 \\
Hydraulic Conductivity & & & & & \\
Electrical Conductivity us/cm & 5 & 3 & 10 & 0 & 0 \\
\hline
\end{tabular}

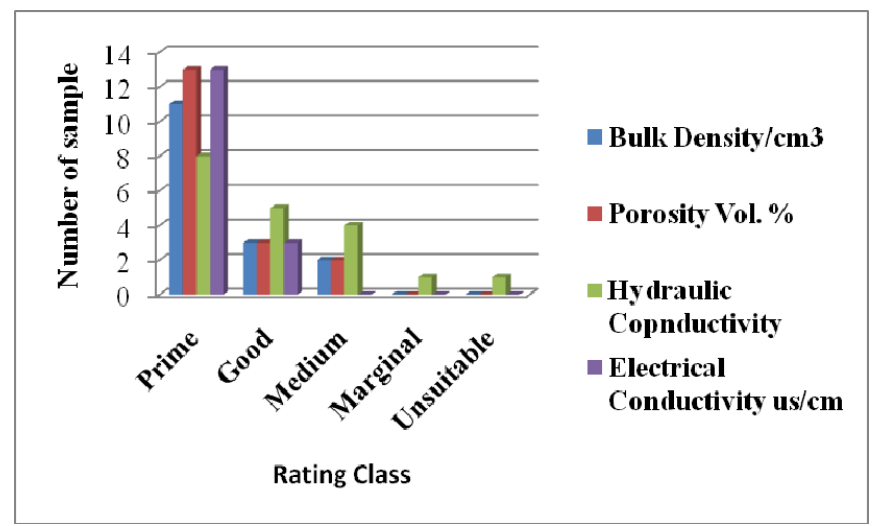

Figure 7.1a. Bar Chart showing Rating Class of Hydraulic Properties of Olokemeji Plantation

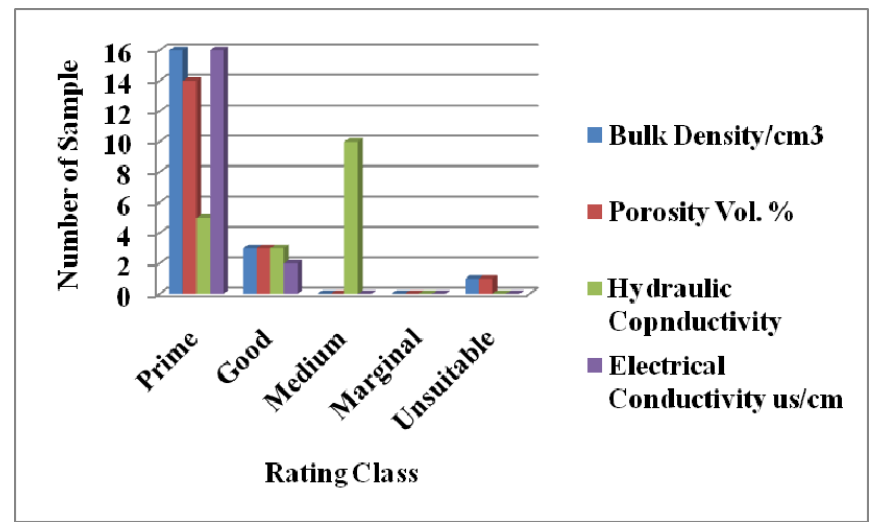

Figure 7.1b. Bar Chart showing Rating Class of Hydraulic Properties of Ilaro Plantation

\section{Hypothesis tested is as stated below:}

For the hypothesis on the differences in the physical properties of Teak Plantations under the basement (Olokemeji) and sedimentary rock formation (Ilaro), the results revealed that there is no significant differences in the physical properties of the soils between the basement complex and the sedimentary formation in terms of all the mean concentration of Hydraulic Capacity (K), water holding capacity, (WHC), Bulk density (BD), Porosity, Electrical conductivity (EC) and the grain size particles such as (sand, salt and clay) with the $p=0.755>0.05$. The hypothesis is therefore accepted.

For the Primary test on whether there is significant differences in the physico - chemical properties of Teak plantation under basement and sedimentary rocks or not. The statistical methodology adopted was independent samples T-test to compare the mean concentrations of $\mathrm{pH}, \mathrm{EC}$, TDS and Temperature between the two locations. The results revealed that there is statistically significant difference between basement complex and sedimentary rock on the mean concentration of $\mathrm{pH}$ only with $\mathrm{P}=0.086>0.05$. While on the other hand, there are no statistical 
significant differences on the mean concentrations of EC, TDS and Temperature with $\mathrm{P}=0.017,0.016$ and $0.000<$ 0.05 respectively. In conclusion, the statistical analysis revealed that among the four physico-chemical properties studied it is only $\mathrm{pH}$ that shows statistical significant difference between the two locations.

For the secondary test between the horizons, the independent sample T-test was applied to compare the two horizons where samples were collected from. The result revealed that there is no statistical significant difference between $\mathrm{A}$ and $\mathrm{B}$ horizon on the mean concentration of the $\mathrm{pH}$, EC, TDS and Temperature. The $\mathrm{P}$ values of the elements are $\mathrm{P}=0.697,0.241,0.244$ and $0.723>0.05$ for $\mathrm{pH}$, Electrical Conductivity (EC), Total Dissolved Solid (TDS) Temperature $\left({ }^{\circ} \mathrm{C}\right)$ respectively.

\section{Conclussions and Recommendation}

The results of this work have clearly shown that there are statistical differences, though, some of the differences are significant while some are not based on different hypothesis posited for the soil's physical and chemical properties and nutrients under different parent materials in Teak plantations of the two study sites. The results is a reflection of the physical and physicho-chemical properties of soils under two distinct parent materials and the influence of the underlying rock on the top and sub-soil in monoculture plantation environment. A further study on the effect on the vegetation is required to see how the parent rocks further affect the biological environment. By and large, a critical geographical, pedological (lithological) and edaphic analysis and appraisal is required before sitting a monoculture plantation.

\section{References}

Aborisade, K. D., \& Aweto, A. O. (1990). Effect of exotic tree plantations of teak (Tectona grandis) and gmelina (Gmelina arborea) on a forest soil in south-western Nigeria. Soil Use andManagement, 6(1), 43-45.

Adams, W. A. (1973). The effect of organic matter on the bulk and true densities of some uncultivated podzolic soils. J. Soil Sci., 24, 10-17. http://dx.doi.org/10.1111/j.1365-2389.1973.tb00737.x

Adejuwon, J. O., \& Ekanade, O. (1988). Soil changes consequent upon the replacement of tropical rain forest by plantations of Gmelina arborea, Tectona grandis and Terminalia superba. Journal of World Forest Resource Management, 3, 47-59.

Adeyoju, S. K. (1971). A synopsis of Nigeria Timber Economy, Nigeria for Inf.

Federal Department of Forestry. (1999). Forest Inventory, Management, Planning, and Recommendations (FORMECU). Revised National Report Vol II. Beak Consultants Limited.

Jorgensen, J. K., \& Wells, C. G. (1986). Tree nutrition and fast growing plantations in developing countries. The International Tree Crops Journal, 3, 225-244. http://dx.doi.org/10.1080/01435698.1986.9752795

Jose, A. L., \& Koshy, N. M. (1972). A study of the morphological, physical and chemical properties of soils as influenced by teak vegetation. Indian Forester, 98(6), 338-348.

Juo, A. S. R., \& Manu, A. (1996). Nutrient effects on modification of shifting cultivation in West Africa. Agric. Ecosys. Env., 58, 49-60. http://dx.doi.org/10.1016/0167-8809(95)00656-7

Kogbe. (1976). Geology of Nigeria. C. A. Lagos: Elizabethan Publishing Co.

Miller, R. M., \& Gardiner, D. T. (2001). Soils in Our Environment. New Jersey: Prentice-Hall., Upper Saddle River.

Ombina, C. A. (2008). Soil Characterization for Teak (Tectona grandis) plantations in Nzara District of South Sudan, Department of Forestry, Stellen Bosch University, Gabon.

Raymond, K. M. (1996). A Consortium Support Model for greatly increasing the contribution of quality tropical hardwood plantations to sustainable development. Amsterdam: The Amazon Teak Foundation.

Whittaker, R. H., Borman, F. H., Likens, G., \& Siccama, T. G. (1979). The Hubbard Brook ecosystem study: forest biomass and production. Ecology Monograph, 44, 233-254. http://dx.doi.org/10.2307/1942313 